\title{
Consolidating Rural Pennsylvania Local Government: A Taxpayer's Choice
}

Geoffrey Tickell, Indiana University of Pennsylvania, USA

\begin{abstract}
This paper presents a case for the amalgamation of local government municipalities in parts of the US and, in particular, rural Pennsylvania (PA). It presents a case by first examining recent international trends in local government management including council consolidations (or mergers) and second, by showing that municipalities in rural PA are, for the most part, too small to: 1) be democratically effective, 2) attract and retain quality management, and 3) deliver the services their constituents expect. This paper concludes by suggesting that the present structure of local municipalities in rural PA is out of date and reform is needed.
\end{abstract}

Keywords: Local government, Consolidation, Amalgamation, Pennsylvania

\section{INTRODUCTION}

$\mathcal{D}$ uring the past two decades, many western nations, including New Zealand, Australia, the USA, and Canada, have undergone significant public sector reform. The overriding objective of this public sector reform (often referred to as "new public sector management") has been to require government entities to adopt private sector practices so as to become more efficient and more accountable (OECD, 2005). These reforms have included, but are not limited to, the introduction of public sector accounting standards (GASBS, IPSAS), the migration from cash to accrual accounting (Guthrie, 1998), an increasing requirement to have government sector financial statements audited by private sector accounting firms, job contracts and performance bonuses, and amalgamations of local governments (Nelson, 1990).

This paper presents arguments for and against consolidating small local governments by comparing the merging of local governments in the state of Victoria, Australia during the mid-1990's, with the apparent need to merge many local municipalities in the state of Pennsylvania, USA. This paper also makes reference to other states within Australia that are considering pursuing local government mergers and other states in the US that should also consider such mergers.

\section{LITERATURE REVIEW}

On October 6, 1992 after many years of Labor Party rule, Victorians elected a "Jeff Kennett" led Liberal/National Party to state government in an overwhelming majority (see Carlin, 2003). The Kennett era, as it is known, lasted seven years. Somewhat surprisingly, the Liberal/National Party lost the 20 October 1999 election to a Steve Bracks led Labor Party. However, during those seven years of the Kennett era, many significant and dramatic reforms were implemented (Carlin, 2005). One reform was to reduce, through amalgamations, the 210 local governments that existed in 1994 to only 78 by 1996 (Local Government Association, 2008). Thus, the average population of each local government increased from 21,000 to 62,000 and the average land coverage almost tripled from 600 square miles to 1800 (Jones, 2006).

In 1994, the Kennett Government brought about forced amalgamations of local municipalities by dismissing the 2000 plus democratically elected councilors and replacing them with 210 commissioners (one for each municipality) to implement the reform process. Two years later, the task was complete and the new larger municipalities could return to democrat rule through local government elections, albeit with now only 600 representatives (instead of over 2000). During the transition, the Commissioners undertook the task of managing the 
day-to-day activities of the council and implementing the Kennett Government policies for municipalities to consolidate with neighboring councils.

One example of this forced amalgamation process is that of the Mornington Peninsula Shire. At the beginning of 1994, three local governments operated on the Mornington Peninsula; namely the Mornington Shire, Flinders Shire and the Westernport Shire. At the end of 1996, the three councils were now one, known as the Mornington Peninsula Shire (Mornington Peninsula Shire, 2008). Hence, the revenues, expenses, and responsibilities of formerly three shires are now the responsibility of one shire bounded by almost the same boundary as the former three. In 1996, the three Commissioners resigned their positions and were replaced by a group of 11 elected councilors.

The benefits of such consolidations outlined by the Kennett Government and other proponents (Boyne, 1995) were based on the theory of economies of scale; that is, better services provided to constituents for less property taxes. In fact, in 1994, upon replacing the councilors with Commissioners, the Kennett Government reduced property taxes (known in Australia as "Rates") by $20 \%$.

The Mornington Peninsula Shire population, as of 2006 Census, was 140,000 people on a land area of 280 square miles. The Mornington Peninsula Shire is the only local government body for that area. It comprises eleven wards each represented by one councilor with each ward having approximately 12,000 registered voters. In the most recent general election of 2005, all wards except one were contested by an average of three candidates. A $75 \%$ voter turnout and a preferential system of voting meant that the successful candidate required at least 4,500 votes. That elected official represents about 12,000 voters.

The state of Victoria today comprises 79 local governments of which all have defined and clear boundaries that do not overlap or overlie (i.e., there are no donut municipalities). They are called cities or shires depending upon their population size. They are the third and final tier of government within Australia; that is, there are no governing bodies within a city or shire municipality. Each has their own extensive website containing the required links for citizens to access the information they seek and to make payments through e-commerce.

In the US, 48 of the 50 states in the US have operational county governments although Alaska and Louisiana call their counties boroughs and parishes respectively. Connecticut and Rhode Island have geographic regions called counties, but they do not have functioning governments. Hawaii and Delaware have the fewest counties (4 and 3 respectively) while Texas has the most (254). Overall, the US has 3,033 counties of which there are 33 city-county governments (e.g., Jacksonville/Duval City/County). Counties in the US vary significantly in size and population. The largest county by population is Los Angeles, California (nearly 10 million people) while the smallest is Loving County, Texas (with 67 residents living in 31 households). The smallest county by land area is Arlington County, Virginia (26 square miles) while the largest is North Slope Borough, Alaska (87,860 square miles). Counties comprising populations under 50,000 account for nearly three-fourths of all county governments in the US (NACO, 2008). Within the county structure of government for most states lie smaller local governments called cities, townships or villages, most of which are incorporated and have elected government. Nelson describes local government in the US as a "crazy quilt" of overlapping boundaries (Nelson, 1990). For example local government in Pennsylvania is a "mosaic" of 5,334 individual units with each unit being independent, although geographic overlap is common. As of 2001, Pennsylvania comprised 67 counties, 56 cities, 964 boroughs, 1 incorporated town, and 1,548 townships (Greene County, 2008).

To further illustrate, Indiana County, located in Western Pennsylvania (approximately 60 miles east of Pittsburgh), has a population of around 90,000 people on a land area of 834 square miles. Hence it is slightly less populated but larger in area than the Mornington Peninsula Shire. Within its boundaries, Indiana County includes 14 Boroughs and 24 Townships. Borough populations range from 131 people to 14,895 while Township populations range from 696 to 14,034. The average land size of a Borough is less than one square mile while the average for a Township is 30 square miles.

In the recent general elections held throughout Pennsylvania on November 6, 2009, all townships and boroughs within the Indiana County held elections. Thus, there were 38 incorporated governments holding elections 
for a population of 90,000 people. For the Borough of Armagh (the smallest incorporated government in the county), the registered voting population is 87 of which 32 (37\%) cast a vote, although not for all positions. Not surprisingly, in this small rural town of 100 people, no candidates stood for the positions of Borough "Auditor" or "Constable" or "Council". In fact, of the 37 jurisdictions within the Indiana County, there were candidates for the position of Auditor in only 12, with one candidate requiring only 95 votes to win the first-past-the-post election. For the other 25 jurisdictions, there were no candidates. In the largest populated $(14,895)$ incorporated government body, Indiana Borough, divided into four wards, the three candidates of Ward 1 contested 794 votes. This is in a municipal ward of 1,345 registered voters; a 59\% voter turnout. Furthermore, of the three person race, two candidates were to be elected. Add to this the fact that one incumbent for each ward of Indiana Borough was not required to stand for re-election and we have 10 councilors representing approximately 15,000 people or 1,500 each (County of Indiana, 2008). The position of Mayor for Indiana Borough was decided by 126 voters. Furthermore, Indiana Borough is a donut municipality of one square mile; that is, it is entirely surrounded by White Township.

A neighboring state of Pennsylvania is Ohio. It appears from a search of relevant websites that the local government structure of Ohio is similar to that of Pennsylvania; that is, governments are formed at the city, township, and village level within each county. Similar to Pennsylvania, some of the townships have very small populations. For example, Logan County of Ohio has a population of about 46,000 people. Within its boundaries it includes one city (Bellefontaine), 11 villages, and 17 townships. The County holds elections for three commissioners, an auditor and other positions, while the city and each of the villages hold elections for mayor, councilors and auditor. The townships have elections for three trustees each and a clerk. Monroe Township has a population of only 1500 people. One could say that this is one Trustee representing 500 people.

Another neighboring state of Pennsylvania is New York with 62 counties. The population of the county of Niagara is 216,000 . This county encompasses three cities, five villages and 12 townships. The township of Wheatfield has a population of 15,000 and has one supervisor and four elected "councilmen-at-large" (Niagara County, 2008). That is a ratio of one representative per three thousand citizens.

The nearby state of Indiana includes 92 counties. The largest, Marion County, has 750,000 residents while the smallest, Ohio County, has only 5,000 on 87 square miles. Within Ohio County there is one incorporated township (i.e., Rising Sun) and four townships. This city of Rising Sun has a population of 2,500 on a land area of 1.5 square miles. It elects a mayor and councilors. The smallest township is Pike (362 people). It also has an elected government.

For many of these boroughs, cities and townships throughout the US, one is surrounded by another (hence they are known as donut councils). Thus, the residents of these cities are often directly and indirectly governed by the city, the town, the county, the state and the nation; and paying taxes directly or indirectly to all. According to Nelson (1990), the highest concentration of taxing authority's $(n=941)$ and general-purpose governments $(n=318)$ in the US exist in Chicago.

It is argued in this article that the citizens of many states in the US are being overgoverned. Furthermore, they are paying the price for being overgoverned with higher taxes and less services. The merging of these small local governments into larger ones is required for citizens of these municipalities to receive the services they warrant in the $21^{\text {st }}$ century.

\section{METHOD}

It is apparent from the statistics offered in this paper that the citizens of Indiana Borough, and presumably other boroughs and townships throughout Pennsylvania and similar states in the US, are much more highly represented than citizens living on the Mornington Peninsula or other Australian municipalities. That is, 1500 for each councilor on the Indiana Borough compared with 12,000 for each Mornington Peninsula councilor. And, this does not include representation from the Indiana County Commissioners for the citizens of Indiana Borough. Add to this the fact that many incorporated governing bodies within the boroughs and townships of Indiana County did not attract candidates in the last general election to fill vacancies and it appears that there is a case for many local governments in Pennsylvania to be consolidated. 
The cost per taxpayer for services provided is a major consideration when evaluating the efficiency of local government structures. The Mornington Peninsula Shire budget, a 237 page document, (Mornington Peninsula Shire, 2008) shows revenues for the $2008 / 2009$ financial year to be $\$ 105$ million. That is, approximately $\$ 840$ per head of population. Property taxes (known as Rates) for home owners living in the Mornington Peninsula Shire for 2008 are set at $\$ 0.002$ on the capital improved value of the home. For a $\$ 200,000$ home (median price $=$ AUD337,000), the Rates would amount to around $\$ 400$ per year. In comparison, property taxes for home owners in Indiana Borough average $\$ .02$ on the capital improved value. Therefore, the property taxes on a $\$ 200,000$ home (median price $=$ USD94,000) would approximate $\$ 4000$. Thus, on property taxes alone, the local government of Indiana Borough is charging ten times more than those of the Mornington Peninsula. Furthermore, the Indiana Borough also collects income taxes. In Australia, only the federal government collects income tax.

Although it is difficult to quantifiably compare the services provided by both local governments (i.e., Indiana County vs. Mornington Peninsula Shire), a "drive-around assessment" comparing the conditions of the roads and pavements, the quality of the parks, gardens and bike trails, and the overall appearance of the government buildings (e.g., public libraries, sport stadiums, municipal offices), would demonstrate to the visitor to each area that local government of the Mornington Peninsula is able to provide many more modern-day services than those of many counties, cities, townships, or boroughs in north-east US. One clear example is that pavements in Australia are maintained in good repair by each municipality whereas in Pennsylvania it is the property owners' responsibility to maintain the pavement outside of their home. This paper argues that the extra layers of government in the US are inhibiting progress and increasing costs. A major overhaul of local government within the US, with financial support from the states, is likely, in the long-term, to improve services provided by these counties, cities, townships and boroughs.

\section{DISCUSSION}

The benefits of amalgamating local governments are as follows:

- $\quad$ Economies of scale allow for more services to be provided at a lower cost per household. For example, one council, rather than 38 , representing a similar geographic area and a similar population size requires only one web-site rather than 38 web-sites. A quick review of the web-sites available illustrates that the Mornington Peninsula Shire web-site is of superior quality than any of the 38 web-sites within Indiana County. Few boroughs and townships within Indiana County have a web-site. For example, the Indiana Borough, the most populous local government in the County, does not presently have a website.

- $\quad$ Larger municipalities lead to a larger tax base and therefore allow each municipality to offer larger salaries thereby attracting higher quality employees/management. By way of comparison, the Mayor of the Mornington Peninsula Shire receives an annual salary of at least $\$ 57,500$ and is reimbursed up to $\$ 20,000$ for out-of-pocket expenses. The position of Mayor of Mornington Peninsula Shire is deemed to be parttime enabling the Mayor to maintain his/her fulltime job (Local Government Victoria, 2007). No information is readily available on the Mayor of Indiana Borough's remuneration package. It is likely to be small.

- A smaller number of elected seats on local government suggests that more candidates would compete for each position and therefore the winning candidate would be of higher quality.

- $\quad$ Larger local governments with more highly skilled personnel and larger budgets will be able to negotiate more effectively with state and federal governments and private corporations. That is, these larger municipalities obtain a more powerful bargaining position (Mackay, 2007).

- Where overlapping boundaries exist, amalgamations resulting in clear boundaries would reduce anomalies in this current double or triple government scenario.

- Within the newly formed larger municipality, areas that had been neglected by the previous council, due to insufficient funds, could have funds allocated to them to modernize the area. Using the Robin Hood approach, taxes from the richer neighborhood could be channeled into the poorer neighborhood so that the whole county improves. For example, after the 1996 amalgamation of the three local governments on the Mornington Peninsula, the poorer neighborhood (formerly the Shire of Westernport) had funds allocated to them from the richer neighborhood (formerly the Shire of Mornington) to build a modern indoor swimming center, thereby improving the quality of life, civic pride and land values for those living in the Westernport 
area. Other neglected facilities in the area (e.g., sporting fields, libraries, parks \& gardens) were also improved substantially. This equity issue could be regarded as the most significant benefit of council amalgamations.

The costs of amalgamating local governments could be regarded as follows:

- $\quad$ The larger local government loses touch with its citizens and the citizens no longer have the voice that they previously had in the smaller government. That is, the ratio of representative to constituent diminishes and a citizen is not personally knowledgeable of each representative and each candidate and therefore loses interest in the processes of local government (Dollery, Byrnes, \& Crase, 2007).

- Many citizens would be required to travel further to attend meetings that were previously nearby and therefore, again, might lose interest in council proceedings (The Age, 2004).

- $\quad$ Many citizens could be required to drive further to comply with the legal requirements of the county (e.g., licenses \& court hearings). However, satellite offices and the internet are means of minimizing this disadvantage.

- Transition costs as a result of neighboring municipalities merging are substantial (McKinley Douglas Limited, 2006). It is important in any state government initiated local government amalgamations that the state government funds these transition costs.

\section{CONCLUSION}

It appears through observation and research that there is a case for the Pennsylvania government, and possibly other similar state governments of the US, to follow the lead of many other western nations and pursue local government reform through local government consolidations. This paper postulates that there are too many local governments and they are not maintaining the infrastructure or providing the services for which their citizens are providing taxes. Typically, the townships and boroughs represent too small an area and too few people and therefore collect too few taxes to perform their role efficiently and effectively. Furthermore, many of these small governments cannot arouse enough interest in the citizens they represent to find candidates for the elections. The population-size of Indiana County and the Mornington Peninsula are similar and it is argued that, as with the Mornington Peninsula Shire, Indiana County, after a restructure, could become the one and only government administering the county, and it could do so more effectively and more efficiently than the present 38 incorporated governments. The states of Hawaii and Delaware have adopted this "county-only" government model. For example, the State of Hawaii has only four counties with no other formal government bodies within each county. The County and City of Honolulu elects nine councilors to represent its 900,000 population (Hawaii Government, 2008).

Finally, it should be noted that the issue of local government consolidation can be a very personal issue for residents of the "proposed-to-be-consolidated" municipality, as it is that arm of government where their daily lives are touched and affected by government, and it is that level of government, far more so than state or federal, that they feel they have the power to influence and make a difference (Bish, 1996). This feeling of attachment and ownership is very evident in the discussion taking place in areas that are presently seriously considering merging local governments (e.g., Queensland, Australia \& Quebec, Canada). However, this paper proposes that, in the longterm (e.g., 10 years post amalgamations), the transition pain is forgotten and the citizens of the new larger municipality receive better services for less taxes.

\section{AUTHOR INFORMATION}

Geoffrey Tickell, Ph.D, CPA, is Associate Professor of Accounting at Indiana University of Pennsylvania. He holds a Bachelor of Education and a Graduate Diploma of Business (Accounting) form Deakin University, and a Doctorate from Monash University. He has taught higher education for over 20 years. His research interests include government sector accounting and accounting education. 


\section{REFERENCES}

1. Bish, R. L., "Amalgamation: Is it the solution?" Paper presented at The Coming Revolution in Local Government conference, 1996.

2. Boyne, G. "Population size and economies of scale in local government", Policy \& Politics, 23 (3), 1995, 213-222.

3. Carlin, T. M., "Debating the impact of accrual accounting and reporting in the public sector", Financial Accountability \& Management, 21(3), 2005, 309-336.

4. County of Indiana, Indiana County, Pennsylvania, December 2008; www.countyofindiana.org

5. Dollery, B., Byrnes, J., \& Crase, L., An Analysis of the New Perspective on Amalgamation in Australian Local Government; December 2008, www.une.edu.au/clg/wp/02-2007.pdf

6. Greene County, Municipalities within Greene County; December 2008, www.co.greene.pa.us/secured/gc/depts/eo/twp/municipality.htm

7. Guthrie, J., "Application of accrual accounting in the Australian Public Sector - Rhetoric or reality", Financial Accountability \& Management, 14(1), 1998, 1-19.

8. Hawaii Government, December 2008; www.hawaiischoolreports.com/symbols/government.htm

9. Indiana Borough, Welcome to Indiana; December 2008; www.indianaboro.com

10. Mackay, J., Professor spreads the benefits of local government amalgamation; December 2008, www.abc.net.au/capricornia/stories/s1907967.htm

11. Jones, I., Background to amalgamation, December 2008; www.clifton.qld.gov.au/documents/Background\%20to\%20Amalgamation.pdf

12. Local Government Association, Local Government in Victoria, Australia, December, 2008, www.international.lga.gov.uk/features/2007/Local_Government_in_Victoria_Australia

13. Local Government Victoria, Victorian Local Government Councilor Remuneration Review; December 2008; www.localgovernment.vic.gov.au

14. McKinley Douglas Limited, Local government structure and efficiency. Wellington, New Zealand: Local Government New Zealand, 2006.

15. Mornington Peninsula Shire, December 2008, www.mornpen.vic.gov.au

16. NACO, Overview of County Government, December 2008;www.naco.org

17. Nelson, M. A., "Decentralization of the subnational public sector: An empirical analysis of the determinants of local government structure in metropolitan areas in the US", Southern Economic Journal, 57 (2), 1990, 443-457.

18. Niagara County, Niagara County - towns, cities, villages, December 2008; www. niagaracounty.com

19. OECD, Modernising government: The way forward, OECD, 2005.

20. The Age, Kennett's Blitz a decade on; December 2008, www.theage.com.au/articles/2004/04/24/1082719671977.html?from=storyrhs 